\title{
THE INFLUENCE OF THE NATIONAL GAS INFRASTRUCTURE DEVELOPMENT ON POLISH ENERGY SECURITY
}

\begin{abstract}
Geographical location of Poland in relation to the location of the world's largest natural gas deposits causes that, the key to optimizing national gas safety policy lies in conducting reasonable exploitation of domestic reserves and developing the natural gas infrastructure. The milestones are the interconnections and the LNG terminal. After the political transformation the government in its strategic documents repeatedly emphasized the need to ensure Polish energy security through diversification of natural gas supplies. At that time the transmission network was adjusted to import natural gas exclusively from the East. However, for more than fifteen years the only completed project within diversification of directions of natural gas supplies was one interconnector (in Lasów) with limited capacity. Completed over the past several years projects have significantly increased the security of the natural gas supplies. The national operator has started developing the capacity of the underground gas storage facilities which are extremely important for the national gas system. What is more, currently a gradual transformation of the domestic gas market towards its liberalization can be observed, including creating, for this purpose, platforms to purchase imported natural gas and gas trading points called gas hubs. Numerous changes in the Polish gas sector in terms of diversification of gas supplies should be assessed positively. The article outlines key investments in infrastructure, including LNG terminal and highlights its importance in building full integration with the European gas market.

Keywords: natural gas, energy security, gas infrastructure, underground gas storage.
\end{abstract}

\section{INTRODUCTION}

In the early 90's of the last century the need to increase Polish energy security through diversification of natural gas supplies was noticed. At that time the transmission network was adapted to import natural gas to Poland only from the East, which was the consequence of historical determinants and the geographical location of Poland. In recent years a number of investments have been completed to adjust the domestic natural gas

\footnotetext{
${ }^{1}$ MSc Eng.Marcin Łoś, AGH University of Science and Technology, Faculty of Drilling Oil and Gas, A. Mickiewicza Av. 30, 30-059 Krakow, marcinlos@ poczta.fm

${ }^{2}$ MSc Eng.RafałBiały, AGH University of Science and Technology, Faculty of Energy and Fuels, A. Mickiewicza Av. 30, 30-059 Krakow,

${ }^{3}$ Ph.D.Eng. Piotr Janusz, AGH University of Science and Technology, Faculty of Drilling Oil and Gas, A. Mickiewicza Av. 30, 30-059 Krakow,

${ }^{4}$ D. Sc., Eng.Adam Szurlej, AGH University of Science and Technology, Faculty of Drilling, Oil and Gas, A. Mickiewicza Av. 30, 30-059 Krakow, corresponding author: e-mail: szua@agh.edu.pl
} 
market to the requirements of the EU regulations and to increase security of natural gas supplies.

\section{THE STRUCTURE OF NATURAL GAS CONSUMPTION IN POLAND AND THE EU-28}

Poland is a developing country with increasing primary energy consumption $(0.4 \%$ increase in 2013 compared to 2012). In the same time period countries belonging to the EU-28 noticed $0.9 \%$ decrease in primary energy consumption. The differences should be, above all, related to various trends in economic development in recent years ${ }^{1}$. Primary energy consumption in 2013 in Poland per capita reached about 2.57 toe, which is much lower than the European average (3.31 toe per capita). It seems that if the upward trend of the Polish economy is continuing, the consumption of primary energy in Poland will be increasing, approaching the European average.

Picture 1 shows a comparison of primary energy consumption in Poland and the EU28 countries. In 2013, natural gas with $27 \%$ share was the second most frequently used source of primary energy in the EU-28. In the same year in Poland the largest amount of energy produced basing on fossil fuels and natural gas was the third source with $14 \%$ share of the total primary energy consumption. The differences are caused by historical backgrounds and in the case of Poland significant (large by the European standards) deposits of coal and lignite.

Due to the subject matter the comparison of natural gas consumption in Poland and the EU-28 countries is presented in this paper. The European Union countries (considering inland transport) acquired natural gas from internal directions (where the major suppliers are: The United Kingdom, The Netherlands) and external sources (the key suppliers are: Norway, The Russian Federation and Algeria). In 2013 own production was the biggest source of natural gas in the European Union providing $34 \%$ of the total demand (despite the decrease in domestic production by $0.6 \%$ in comparison to 2012). Globally in 2013 the EU countries consumed about $1.5 \%$ less natural gas than in the previous year (while on the world scale consumption of natural gas increased around the same value). It was caused by a number of factors and it appears that the most important were: increased costs of natural gas production and a relatively high price of crude oil and petroleum products. Another important element causing reduction in the demand for natural gas in the EU was the decline in demand for electricity due to the low economic growth and increasing competition from renewable sources and coal (in 2013 noticed $12.3 \%$ decrease in the use of natural gas in energy sector compared to 2012).

Natural gas consumption in Poland in 2013 achieved a record volume of $16.7 \mathrm{bcm}$. Domestic production satisfied about $25 \%$ of the total demand. The import of natural gas increased by around $0.3 \%$ in comparison to 2012 (picture 2). Gas imported to Poland was supplied in the amount of $11.4 \mathrm{bcm}$ from the East and $1.8 \mathrm{bcm}$ from the EU market ${ }^{2}$. It is hard to predict the future growth rate in demand for natural gas on the Polish market, but it cannot be forgotten that between 2002-2012 there was almost a twofold increase in

\footnotetext{
${ }^{1}$ Szurlej A., Kamiński J., Janusz J., Iwicki K., Mirowski T., Rozwój energetyki gazowej a bezpieczeństwo energetyczne, Rynek Energii, nr 6, 2014, s. 33-38.

${ }^{2}$ BP Statistical Review of World Energy June 2014,http://www.bp.com/content/dam/bp/pdf/Energyeconomics/statistical-review-2014/BP-statistical-review-of-world-energy-2014-full-report.pdf (accessed online, 2015)
} 
imported natural gas from $7.7 \mathrm{bcm}$ in 2002 to $11.6 \mathrm{bcm}$ in $2012^{3}$. To maximize security of gas supplies the natural gas transmission infrastructure should both ensure continuity of supply in crisis situations and its capacity has to be prepared for sudden increase in demand for natural gas so that the gas deficit does not cause the inhibition of the growth in sectors for which gaseous fuel is a key source of energy.

Picture 3 shows the structure of natural gas consumption in Poland and the EU-28. In the European Union the biggest consumer of natural gas was the residential and commercial sector with $44 \%$ share of total consumption. Industry was the second largest consumer with $31 \%$ share (in this sector in 2013 was observed $0.7 \%$ increase in natural gas demand). In Poland the largest consumer of natural gas was industry with $49 \%$ share in gas market. That sector in 2013 consumed about $8.3 \mathrm{bcm}$. On the second place was the residential and commercial sector with $38 \%$ share in the market. It is worth highlighting the differences between Poland and the EU-28 in the scale of use of natural gas in energy sectors. These differences, more than twice as big in the EU, in coming years will probably decrease because of the existing and planned investments in generation units based on natural gas in Poland ${ }^{4}$.

Comparing the gas markets in Poland and in the developed EU-member states itis to be expected that with the liberalization of domestic gas market, the development of transmission infrastructure, integration with member states in the area of a common energy market and assuming forcing the industry to implement the plan of reducing $\mathrm{CO} 2$ emissions - the role of natural gas in Poland will increase.It should be noticed that the current structure of natural gas supplies to member states is largely diverse, but there are still countries with the lack of diversification of supplies. Poland due to the realized in recent years projects is one of those countries which, despite the difficulties dictated by historical and geopolitical circumstances, has done significant work in both the legislative and infrastructure area to increase the security of natural gas supplies and to liberalize national gas market.

\section{THE LIBERALIZATION OF THE POLISH GAS MARKET}

Polish energy security is determined by a number of variables. In near future the most important may be: Polish and EU energy policy, integration of the domestic market with EU internal gas market, the geopolitical situation, diversification of supply, storage capacities, domestic gas infrastructure and EU climate policy. EU internal gas market of countries belonging to the European Union may have a positive impact on interstate cooperation (shown by the experiences of recent years) which was proved to be significant especially in crisis situations and may change gas markets in member states; liberalized market gives the possibility to select the natural gas suppliers basing on equal and transparent rules bringing mutual benefits ${ }^{5}$.

Not without significance may liberalized natural gas market in Poland be. Its main tasks will be: to create and to maintain fair pricing and to allow trade in natural gas on

\footnotetext{
${ }^{3}$ Eurogas Statistical Report 2013,http://www.eurogas.org/uploads/media/Eurogas_Statistical _Report_2013.pdf (accessed online, 2015)

${ }^{4}$ Eurogas Statistical Report 2014, http://www.eurogas.org/uploads/media/Eurogas_ Statistical_ Report_2014.pdf (accessed online, 2015)

${ }^{5}$ Kratochvil, P., Tichy, L., EU and Russian discourse on energy relations, „Energy Policy” 56(2013), s.391-406.
} 
equal terms for all market participants.Currently two documents, which are milestones leading to liberalization in legislation, should be considered. First is anamendment to the act about storage of crude oil, petroleum products, natural gas and proceeding in emergency situations to national fuel security and during disruptions on the petroleum market. The main purposes of the amendment were to liquidate the barriers for new operators from abroad who are planning to start gas trading activities in Poland to enter the domestic market and to facilitate import of natural gas from abroad for one's own use $^{6}$.

The next step was an amendment to the regulation on detailed conditions for the operation of the gas system introducing into Polish law the institution of the virtual trading point, defined as non-physical point located between the point of entry and exit from the transmission system for the sale of natural gas. The functioning of this point allows to separate contractual cash flows of natural gas from its physical flows, and consequently trade for example, through a commodity exchange $\left(20^{\text {th }}\right.$ of December 2012 first listed trade deal of natural gas on the Polish Power Exchange). As part of the amendment to the regulation top range of the Wobbe index was changed from 54.0 to $56.9 \mathrm{MJ} / \mathrm{m} 3$. This change allows fuel received by the LNG terminal in Swinoujscie to enter the national gas system, which is characterized by a slightly higher calorific value ${ }^{7}$.It is worth mentioning that other important tasks have already been completed for example: transmission infrastructure has become available to third parties and transmission infrastructure has been separated from production network.

At the moment the key task in the field of Polish gas market liberalization is releasing natural gas prices for end-use consumers. In addition, a new project proposed by the Council of Ministers specifies the minimum level of diversification of gas supplies from abroad. In the coming years the maximum share of gas imported from abroad from a single source in relation to the total amount of gas sold by the energy company on the territory of the Republic of Poland in a given year could not be greater than $59 \%$ between 2015-2018 and 49\% in 2019-2025 . Extremely important are the changes implemented by the Energy Regulatory Office within the Agency for the Cooperation Energy Regulations. In 2014 were introduced among others Congestion Management Procedures and Gas Capacity Allocation Mechanisms ${ }^{9,10}$.

Progress in liberalization and legislative changes in the environment of the domestic gas market provide tools to change infrastructure, which is the real, physical guarantor of the continuity of supplies to Poland.

${ }^{6}$ Ustawa z dnia 16 września 2011 r. o zmianie ustawy o zapasach ropy naftowej, produktów naftowych i gazu ziemnego oraz zasadach postępowania $w$ sytuacjach zagrożenia bezpieczeństwa paliwowego państwa i zakłóceń na rynku naftowym oraz o zmianie niektórych innych ustaw 2011, „Dziennik Ustaw” 234 (2011), poz. 1392.

${ }^{7}$ Rozporządzenie Ministra Gospodarki z dnia 20 sierpnia 2012 r. zmieniajace rozporzadzenie w sprawie szczegółowych warunków funkcjonowania systemu gazowego, „Dziennik Ustaw”, poz.968(2012).

${ }^{8}$ Government Legislation Centre, https://legislacja.rcl.gov.pl/projekt/12270503(accessed online, 2015)

${ }^{9}$ Urząd Regulacji Energetyki, Liberalizacja rynku gazu, http://www.ure.gov.pl/portal/p1/552/ Liberalizacja_rynku_gazu.html (accessed online, 2014)

${ }^{10}$ Urząd Regulacji Energetyki, URE o zmianach na rynkach energii i gazu w 2014 r. oraz planach na $2015 r$. 


\section{THE STRUCTURE OF NATURAL GAS SUPPLIES TO POLAND AND} THE EU

In 2013, natural gas consumption in Poland was ca. 5 bcm higher than in 1999. Together with the increasing use of natural gas, its volumes procured from different countries gradually increased and the structure of deliveries to our country changed, too. In 1999ca. 62.75\% of imported natural gas came from the areas of Russia, Azerbaijan and Central Asia countries, while in 2013 the share of gas from these regions amounted to ca. $56 \%$ (not including virtual reverse). Summary of the structures of natural gas supplies to Poland in 1999 and 2013 is shown in picture $4^{11}$.

In Poland in the years between 1971-2013 natural gas consumption in energy units increased from ca. $255 \mathrm{PJ}$ to ca. $640 \mathrm{PJ}$, while its import increased from ca. $55 \mathrm{PJ}$ up to 477 PJ (picture 5). Taking into consideration European member states of the Organization for Economic Co-operation and Development (OECD), Poland uses ca. 3.3\% of natural gas out of 19263 PJ. The biggest consumers of natural gas in Europe are countries such as France (1808 PJ), Germany (3403 PJ), Italy (2670 PJ), The Netherlands (1545 PJ) and Spain (1210 PJ), which constitute more than 55\% of the overall natural gas consumption of the OECD Europe member states [10]. Among the countries belonging to OECD Europe the biggest importers of natural gas are countries such as France, Germany, Italy, Spain, Turkey and The UK. The amount of fuel imported by the above mentioned countries constitutes ca. $75 \%$ of the total import of fuel to OECD Europe countries. The volumes and structure of the imported fuel by selected OECD Europe states are presented respectively in pictures 6 and 7 .

\section{THE DEVELOPMENT OF THE DOMESTIC NATURAL GAS} INFRASTRUCTURE

The fundamental element ensuring gas security of each country is skilful diversification of the sources and directions of supplies of a given energy carrier. In the case of natural gas as energy carrier, the factor of vital importance is proper development of infrastructure used for its transportation. Alongside the increased predicted supplies of natural gas for Poland, the domestic gas pipeline network needs to be developed dynamically. Starting with the construction of interconnectors whose main objective is integrating European markets of natural gas, through simultaneous investment in transmission network to the construction and development of underground natural gas storage systems. Based on the analysis of the European natural gas market, it can be observed that access to liquefied natural gas has a growing effect on the structure of gaseous fuel supplies to particular countries. In 2013 the biggest importers of liquefied natural gas comprised countries such as Spain (142.1 TWh), The UK (102.6 TWh) and France (92.4 TWh). The amounts of gaseous fuel imported by EU-28 countries in 2013 decreased by over $29 \%$ compared to 2012 . As much as $51 \%$ of liquefied natural gas in 2013 which was on the EU-28 market, came from Qatar with Algeria being the second biggest supplier of liquefied natural gas with $22 \%$ share and Nigeria $12 \%$ share. Bearing in mind a considerable drop in world prices, it is assumed that by 2015 the level of supplies of this kind of fuel to the EU markets will have increased - picture 8 .

\footnotetext{
${ }^{11}$ Minister Gospodarki , Sprawozdanie z wyników monitorowania bezpieczeństwa dostaw paliw gazowych za okres od dnia 1 stycznia 2013 r. do dnia 31 grudnia 2013 r.
} 
Up to now Poland has not participated in the European market of liquefied natural gas due to the lack of suitable infrastructure for regasification of LNG. The existing situation will change significantly as soon as the key investment for the Polish gas sector has been completed, namely the construction of the terminal for receiving and regasification of liquefied natural gas in Świnoujście. Once the liquefied natural gas terminal comes into full operation, it will become a new access point to the domestic transmission system with the capacity of $5 \mathrm{bcm} /$ year which can be further extended to $7.5 \mathrm{bcm} /$ year. The LNG terminal will consist of two tanks with the capacity of 160 thousand cubic metres each. However, in order to increase regasification capabilities, another liquefied natural gas tank will be built. It is worth mentioning that it is the first investment of this kind in Central Europe and in the Baltic Sea region which will grant access to independent gas sources, which in turn will contribute to Poland's improvement of energy safety. Alongside the construction of the liquefied natural gas terminal, construction works of building an 80kilometre pipeline of DN 800 between Świnoujście and Szczecin as well as the connector to the LNG terminal have been done. Other indispensable infrastructure granting access to the external port has been built - a breakwater, a deep track for vessels and a turntable for ships ${ }^{12}$.

As far as Polish investments uniting European markets of natural gas are concerned, these include building and developing cross-border gas interconnections with neighbouring countries. In 2011, a connection between Polish and Czech transmission systems was opened in Cieszyn. This connection has a technical capacity of $0.5 \mathrm{bcm} / \mathrm{year}$ which can be further extended to $2.5 \mathrm{bcm}$. Building a new connection within the NorthSouth Corridor is another important project on the Polish - Czech border. It includes building a new connection between Polish and Czech transmission systems owing to which technical capacity in the Czech direction can amount to $5 \mathrm{bcm}$ per year. On the other hand, depending on the demand, between 6 to $10 \mathrm{bcm}$ can be transported to Poland ${ }^{13}$.

Another important cross-border gas interconnector which gave access to natural gas from the western direction was the interconnector between the Polish and German transmission systems in Lasów with the capacity of $1.5 \mathrm{bcm}$ which can be further extended to $2.5 \mathrm{bcm}$ per year ${ }^{14}$. As of this year technical capabilities of import of natural gas from the western direction using the Yamal- Europe pipeline have been increased. It was possible due to the development of the access point to the domestic transmission system in Włocławek. As a result, the possibilities of gas import from the western direction by means of virtual reverse flow service on the Yamal-Europe pipeline on the continuous principle have increased by $3.2 \mathrm{bcm} /$ year (continuous flow). Consequently, Poland can import ca. $5.5 \mathrm{bcm} /$ year of natural gas from Germany on a continuous basis through the point Mallnow. Furthermore, if the flow on the Yamal pipeline towards

\footnotetext{
${ }^{12}$ Operator Gazociągów Przesyłowych GAZ-SYSTEM S.A., Plan Rozwoju na lata 2014-2023. http://www.gazsystem.pl/fileadmin/pics_pl/Inwestycje/Plan_Rozwoju_GAZ_SYSTEM_S.A._na_lat a_2014-2023.pdf(accessed online, 2015).

${ }^{14}$ Łoś M., Zmiany na krajowym rynku gazu ziemnego $w$ zakresie infrastruktury, Zeszyty Studenckiego Towarzystwa Naukowego nr 27, Materiały konferencyjne VII Ogólnopolska Konferencja Naukowa „Energia-Ekologia-Etyka”, Wyd. STN, Kraków 2013, s. 69-77, ISNN 17320925 .
} 
Germany is maintained, additionally, capacity on interruptible basis is offered which enables Poland to import ca. $2.7 \mathrm{bcm} / \mathrm{year}^{15}$. Picture 9 shows annual capabilities of natural gas import to Poland which serve as an alternative to the eastern direction.

As can be seen, as a result of recent changes in the gas sector, annual technical capabilities of natural gas import to Poland from the western and southern directions has risen to the level of $10.2 \mathrm{bcm} /$ year. It is worth mentioning that it constitutes $90 \%$ of Poland's overall import needs.

Building a new route of transport of natural gas the so called North-South Corridor is yet another important project in the sector of integration of European gas markets. Within this investment new cross-border gas interconnection between Polish and Slovakian transmission systems will be built as well as the so called Baltic pipeline connecting Polish and Danish transmission systems. The route of the North-South Corridor will run between two liquefied natural gas terminals (LNG terminal in Świnoujście and LNG terminal Adria in Croatia) through such countries as Poland, The Czech Republic, Slovakia, Hungary and Croatia.

Yet another future project of vital importance is building a cross-border gas interconnector between Poland and Lithuania. The planned intersystem connection aims at connecting areas dependent on gaseous fuel supplies from one direction so called "energy islands" with the western transmission system. The pipeline will be ca.562 km long and its minimal capacity should be up to $2.3 \mathrm{bcm} /$ year with the possibility of further extension depending on the needs to $4.5 \mathrm{bcm} /$ year $^{16}$.

Apart from the investment projects focusing on infrastructural integration with the European market, projects connected with the development of the domestic transmission system are being concurrently carried out. At present the Operator of Transmission Pipelines GAZ-SYSTEM S.A. is implementing an investment program for the years 2015-2023, which largely concentrates on the development of high pressure pipelines in western, southern and eastern regions of our country. The above mentioned program assumes building ca. $2000 \mathrm{~km}$ of new transmission pipelines by the end of 2023 .

As far as gas infrastructure is concerned, the most important gas investments in Poland include constructing pipelines between ${ }^{17}$ :

- Szczecin - Lwówek,

- Świnoujście - Szczecin,

- Szczecin-Gdańsk,

- Rembelszczyzna - Gustorzyn,

- Hermanowice - Strachocina,

- Strachocina - Pogórska Wola.

From the point of view of the safety of natural gas supplies to end users, another crucial link is the development of the domestic system of underground natural gas storage facilities (PMG). The summary of current and planned active capacities of respective natural gas storage facilities is presented in table 1.

\footnotetext{
${ }^{15}$ Operator Gazociągów Przesyłowych GAZ-SYSTEM S.A., http://www.gaz-system.pl (accessed online, 2015)

${ }^{16}$ Ibidem

${ }^{17}$ Ibidem
} 
Storage base of high-methane gas includes: PMG husów, KPMG Mogilno, PMG Strachocine, PMG Swarzów, PMG Brzeźnica, and PMG Kosakowo, whereas storage facilities of nitrogen-rich natural gas comprise PMG Bonikowo and PMG Daszewo. At the present moment total active capacity of the storage facilities is ca. $2.75 \mathrm{bcm}$ but owing to the planned investments in the years 2015-2027 it is expected to rise to the level of ca. $3.5 \mathrm{bcm}$ of natural gas.

\section{SUMMARY}

In recent years increase in independence from natural gas supplies exclusively from one direction can be observed. Gradual diversification of the sources and directions of natural gas supplies to our country is taking place. Both completed and planned investments of gas infrastructure contribute to the integration of the Polish gas sector with the European gas market. Investment projects of strategic importance for strengthening Polish energy security are being carried out. Obviously, construction of LNG terminal in Świnoujście is the key project for the Polish gas sector in recent years, owing to which Poland will gain access to new sources of gas fuel. LNG terminal in Świnoujście will grant Poland a share in the global LNG market. Since 2011 rise in possibilities of receiving natural gas from directions other than eastern has been observed. Two newlybuilt cross-border gas interconnections (Poland-The Czech Republic; Poland-Germany development of the existing connection) have contributed to this, whose capacities can be extended as desired. Since the beginning of 2015 technical possibilities of gas import by means of the virtual reverse flow service on the Yamal pipeline have been significantly increased.

All above mentioned infrastructural investments have one common goal which is the improvement of Poland's energy security. The vast investment boom in the gas sector will contribute to the creation of new transit routes and a pipeline system operating and adjusting to the changing conditions of the European gas network. 
Picture 1. Primary energy consumption by fuel in Poland and the EU-28, 2013

Poland

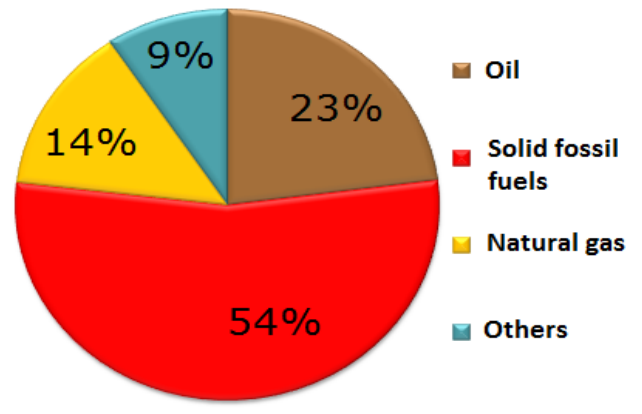

EU-28



Source: own study based on ${ }^{18}$

Picture 2. Consumption (left axis) and production (right axis) of natural gas in Poland, 1993-2013

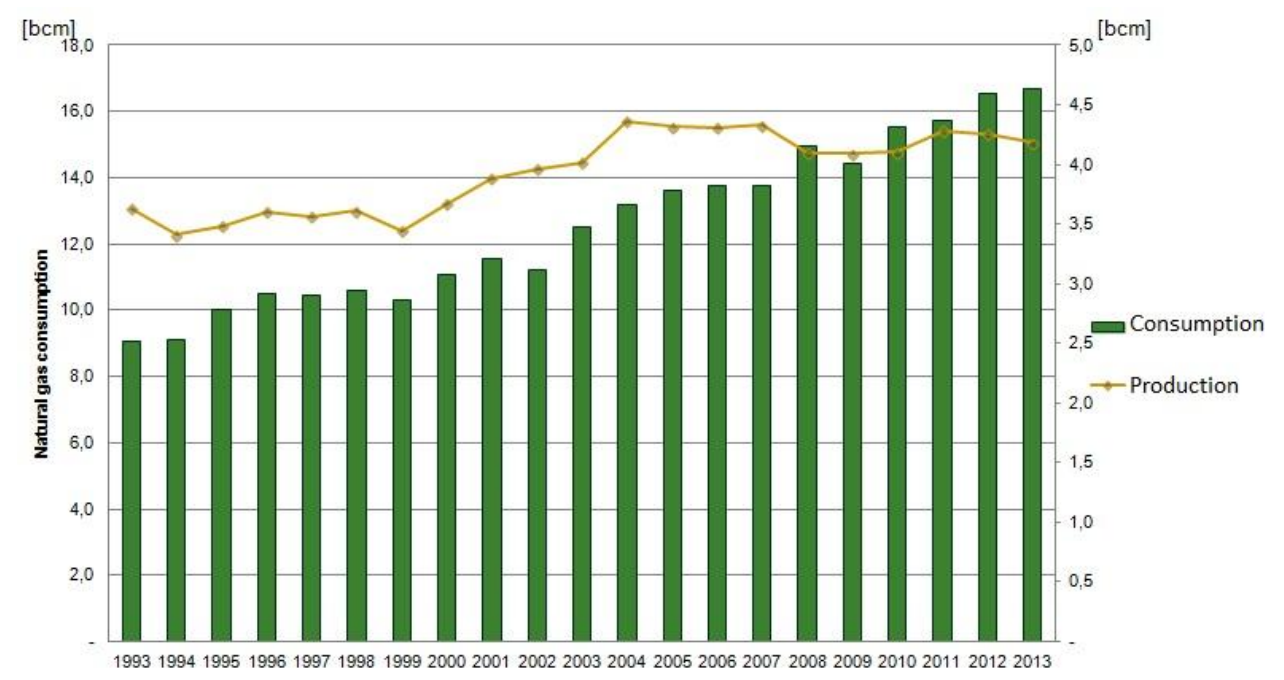

Source: own study based on ${ }^{19}$

\footnotetext{
${ }^{18}$ Eurogas Statistical Report 2014,

http://www.eurogas.org/uploads/media/Eurogas_Statistical_Report_2014.pdf (accessed online, 2015)

${ }^{19}$ BP Statistical Review of World Energy June 2014,

http://www.bp.com/content/dam/bp/pdf/Energy-economics/statistical-review-2014/BP-statisticalreview-of-world-energy-2014-full-report.pdf (accessed online, 2015)
} 
Picture 3. Inland sales of natural gas in Poland and the EU-28, 2013

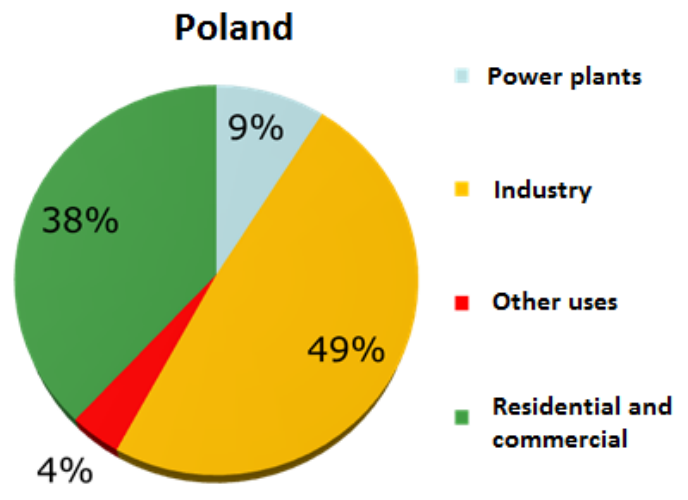

EU-28

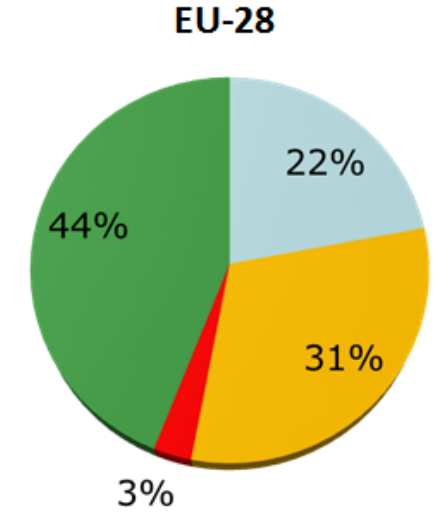

Source: own study based on ${ }^{20}$

Picture 4. The structure of natural gas supplies to Poland, years 1999 and 2013

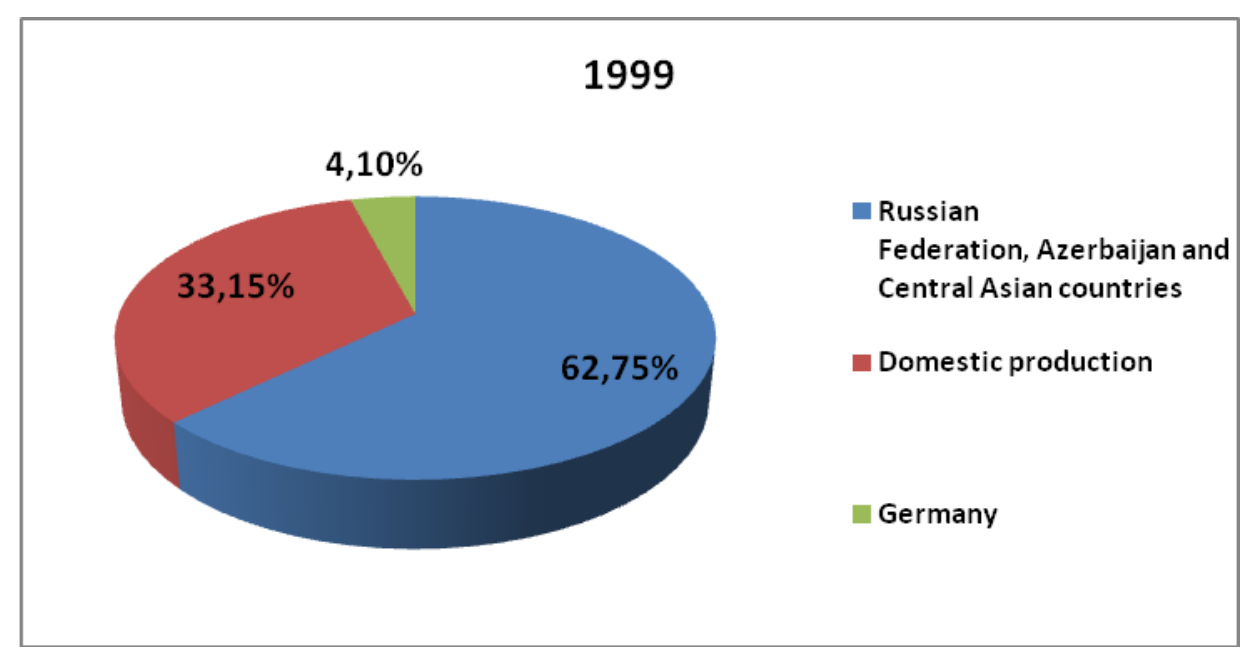

${ }^{20}$ Eurogas Statistical Report 2014,

http://www.eurogas.org/uploads/media/Eurogas_Statistical_Report_2014.pdf (accessed online, 2015) 


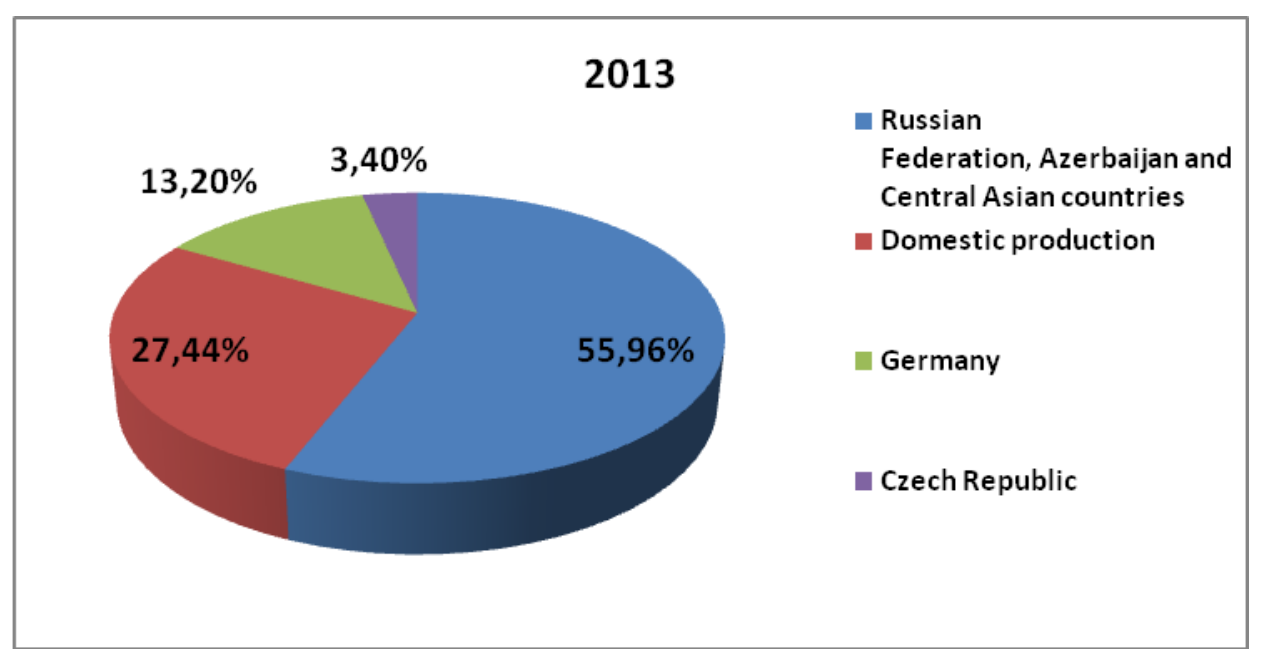

Source: own study based on ${ }^{21}$

Picture 5. Consumption and import of natural gas to Poland, selected years [PJ]

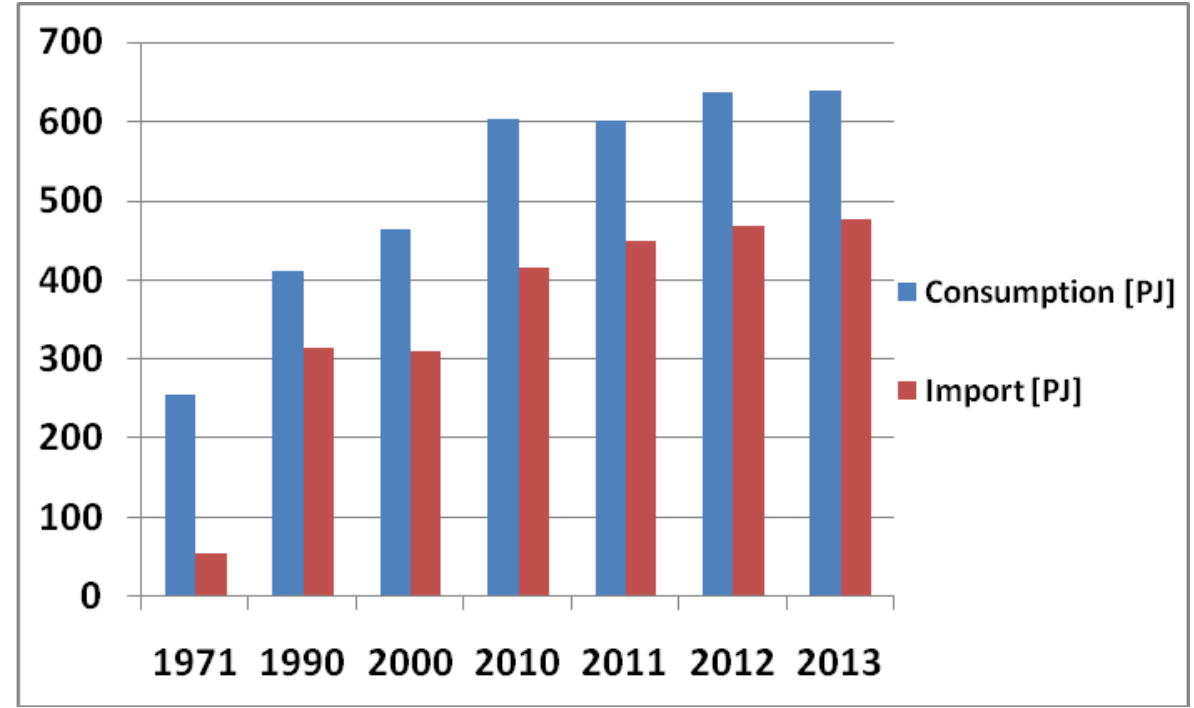

Source: own study based on ${ }^{22}$

\footnotetext{
${ }^{21}$ Minister Gospodarki, Sprawozdanie z wyników monitorowania bezpieczeństwa dostaw paliw gazowych za okres od dnia 1 stycznia 2013 r. do dnia 31 grudnia 2013 r.
} 
Picture 6. Natural gas import to selected OECD Europe countries, 2013 [bcm]

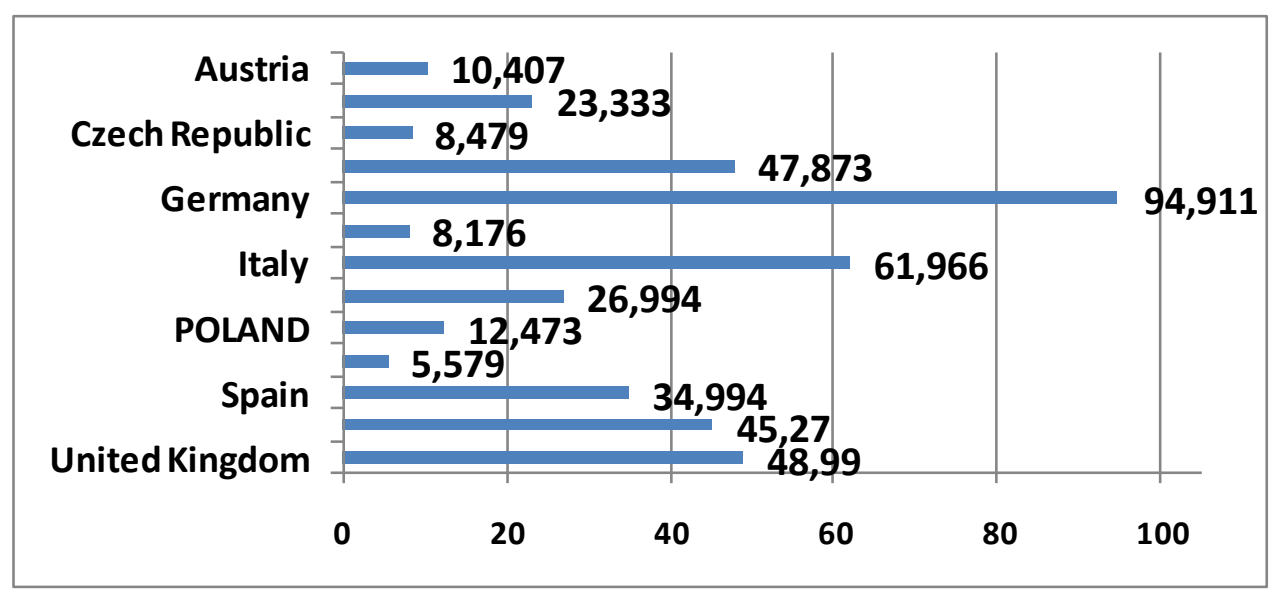

Source: own study based on ${ }^{23}$

Picture7. The structure of natural gas supplies to selected EU-28 countries [TWh]

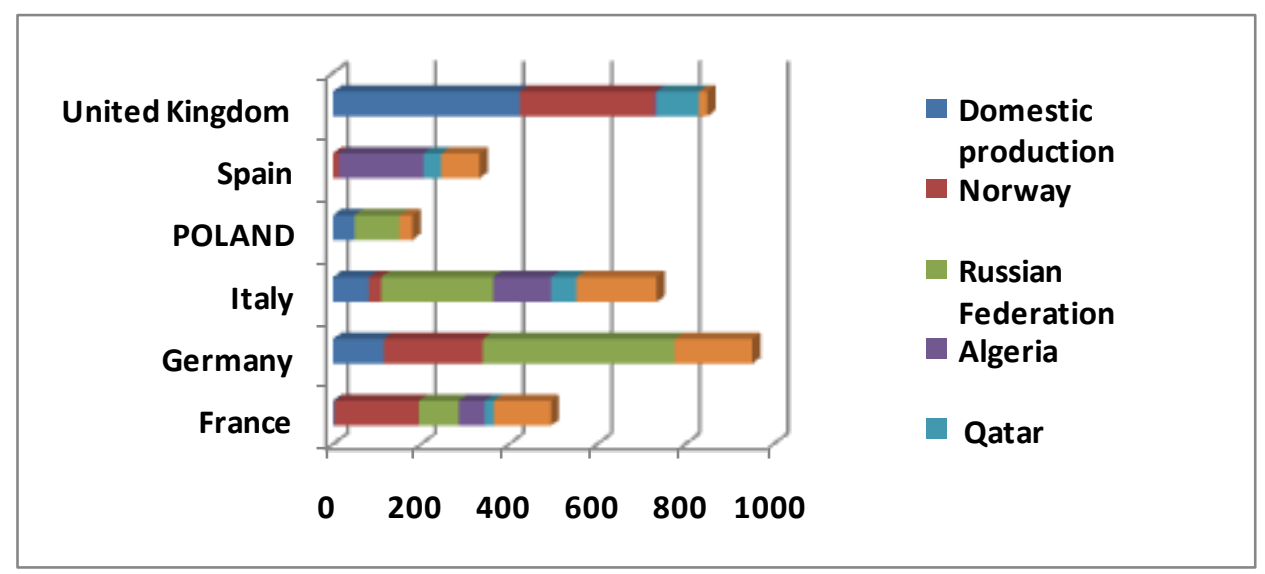

Source: own study based on ${ }^{24}$

\footnotetext{
${ }^{22}$ International Energy Agency - Natural Gas Information 2014

http://wds.iea.org/wds/pdf/Gas_documentation.pdf(accessed online, 2015).

${ }^{23}$ Ibidem

${ }^{24}$ Eurogas Statistical Report 2014,http://www.eurogas.org/uploads/media/Eurogas_Statistical _Report_2014.pdf (accessed online, 2015)
} 
Picture 8. LNG prices in the world (October 2014vs.June 2015)[\$US/MMBtu]

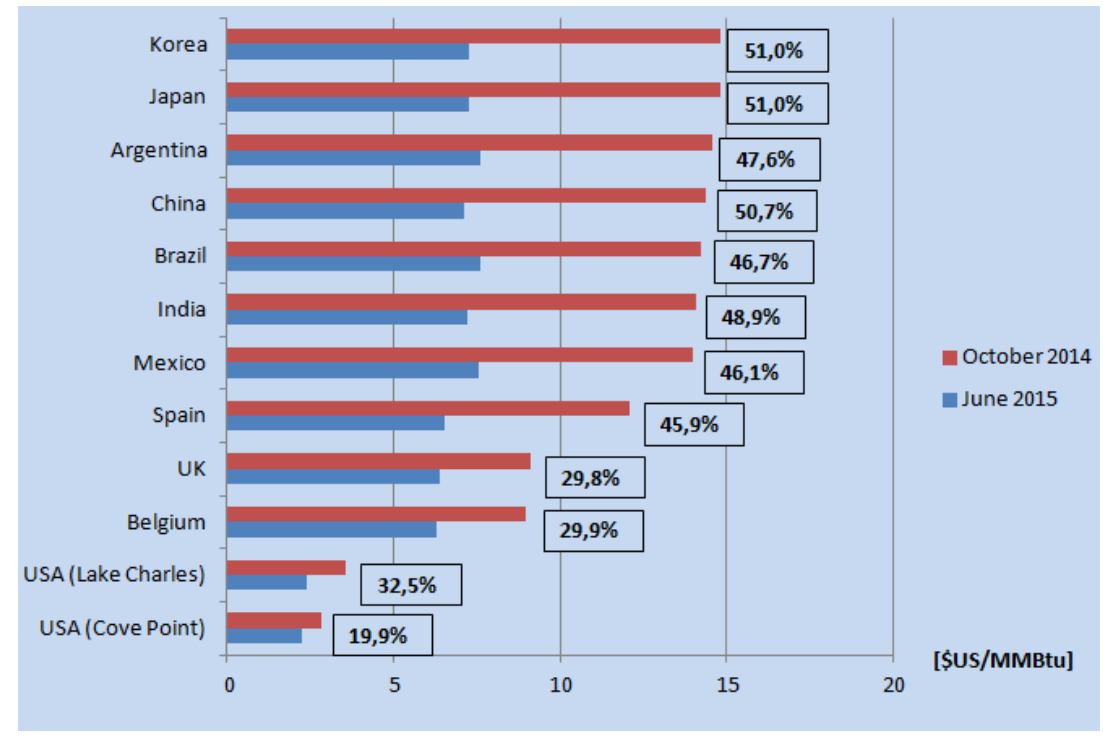

Source: own study based on ${ }^{25}$

Picture 9. Annual technical capabilities of natural gas import to Poland with the exception of the western direction [bcm/year]

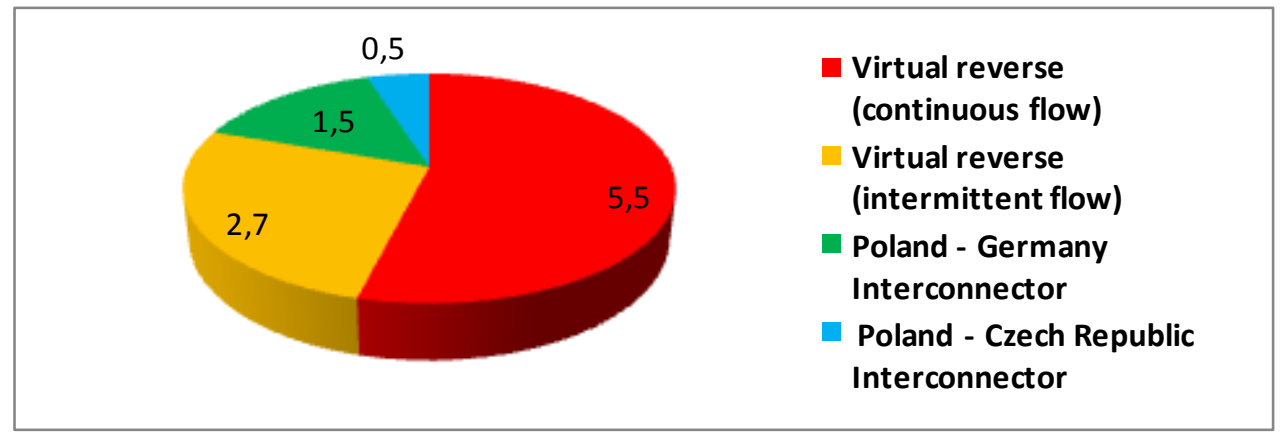

Source: own study based on ${ }^{26}$

\footnotetext{
${ }^{25}$ Federal Energy Regulatory Commission,National Natural Gas Market Overview: World LNG Landed Prices, http://www.ferc.gov/oversight(accessed online, 2015)

${ }^{26}$ Operator Gazociągów Przesyłowych GAZ-SYSTEM S.A., http://www.gaz-system.pl (accessed online, 2015).
} 
Table 1. The summary of current and planned active capacities of respective natural gas storage facilities in Poland

\begin{tabular}{|c|c|c|c|}
\hline Nazwa & 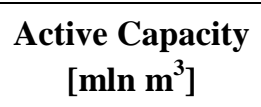 & $\begin{array}{c}\text { Target Capacity } \\
{\left[\mathrm{mln} \mathrm{\textrm {m } ^ { 3 } ]}\right.}\end{array}$ & $\begin{array}{c}\text { Planned } \\
\text { Completion Date }\end{array}$ \\
\hline \multicolumn{4}{|c|}{ High -methane gas storage facilities } \\
\hline Wierzchowice & 1200 & 1200 & - \\
\hline Husów & 500 & 500 & - \\
\hline Mogilno & 408 & 800 & 2027 \\
\hline Strachocina & 360 & 360 & - \\
\hline Swarzów & 90 & 90 & - \\
\hline Brzeźnica & 65 & 100 & 2015 \\
\hline Kosakowo & 51 & 250 & 2021 \\
\hline \multicolumn{4}{|c|}{ Nitrogen-rich gas storage facilities } \\
\hline Bonikowo & 200 & 200 & - \\
\hline Daszewo & 30 & 30 & - \\
\hline Total & 2754 & 3530 & - \\
\hline
\end{tabular}

Source: own study based ${ }^{27}$

\section{REFERENCES}

[1] BP Statistical Review of World Energy June 2014, http://www.bp.com/content/dam/bp/pdf/Energy-economics/statisticalreview-2014/BP-statistical-review-of-world-energy-2014-full-report.pdf (accessed online, 2015)

[2] Eurogas Statistical Report 2013,http://www.eurogas.org/uploads/media/Eurogas_Statistical_Report_20 13.pdf (accessed online, 2015)

\footnotetext{
${ }^{27}$ Polskie Górnictwo Naftowe i Gazownictwo, http://www.pgnig.pl (accessed online, 2015).
} 
[3] Eurogas Statistical Report 2014, http://www.eurogas.org/uploads/media/Eurogas_Statistical_Report_2014.pd $\mathrm{f}$ (accessed online, 2015)

[4] Kratochvil, P., Tichy, L., EU and Russian discourse on energy relations, „Energy Policy” 56(2013), s.391-406.

[5] Ustawa z dnia 16 września 2011 r. o zmianie ustawy o zapasach ropy naftowej, produktów naftowych i gazu ziemnego oraz zasadach postępowania $\mathrm{w}$ sytuacjach zagrożenia bezpieczeństwa paliwowego państwa i zakłóceń na rynku naftowym oraz o zmianie niektórych innych ustaw 2011, „Dziennik Ustaw” 234 (2011), poz. 1392.

[6] Rozporządzenie Ministra Gospodarki z dnia 20 sierpnia 2012 r. zmieniające rozporządzenie $\mathrm{w}$ sprawie szczegółowych warunków funkcjonowania systemu gazowego, „Dziennik Ustaw”, poz.968(2012).

[7] Urząd Regulacji Energetyki, Liberalizacja rynku gazu, http://www.ure.gov.pl/portal/pl/552/Liberalizacja_rynku_gazu.html (accessed online, 2014)

[8] Urząd Regulacji Energetyki, URE o zmianach na rynkach energii i gazu w $2014 \mathrm{r}$. oraz planach na $2015 \mathrm{r}$. http://www.ure.gov.pl/pl/urzad/informacje-ogolne/aktualnosci/5941,URE-ozmianach-na-rynkach-energii-i-gazu-w-2014-r-oraz-planach-na-2015-r.html (accessed online, 2015)

[9] Minister Gospodarki , Sprawozdanie z wyników monitorowania bezpieczeństwa dostaw paliw gazowych za okres od dnia 1 stycznia $2013 \mathrm{r}$. do dnia 31 grudnia $2013 \mathrm{r}$.

[10] International Energy Agency - Natural Gas Information 2014 http://wds.iea.org/wds/pdf/Gas_documentation.pdf(accessed online, 2015).

[11] Operator Gazociągów Przesyłowych GAZ-SYSTEM S.A., Plan Rozwoju na lata 2014-2023. http://www.gazsystem.pl/fileadmin/pics_pl/Inwestycje/Plan_Rozwoju_GAZ SYSTEM_S.A._na_lata_2014-2023.pdf(accessed online, 2015).

[12] Łoś M., Zmiany na krajowym rynku gazu ziemnego w zakresie infrastruktury, Zeszyty Studenckiego Towarzystwa Naukowego nr 27, Materiały konferencyjne VII Ogólnopolska Konferencja Naukowa „EnergiaEkologia-Etyka”, Wyd. STN, Kraków 2013, s. 69-77, ISNN 1732-0925.

[13] Operator Gazociągów Przesyłowych GAZ-SYSTEM S.A.,http://www.gazsystem.pl(accessed online, 2015).

[14] Polskie Górnictwo Naftowe i Gazownictwo, http://www.pgnig.pl(accessed online, 2015).

[15] Szurlej A., Kamiński J., Janusz J., Iwicki K., Mirowski T., Rozwój energetyki gazowej a bezpieczeństwo energetyczne, Rynek Energii, nr 6, 2014, s. 33-38.

[16]Zajdler R., Robert Zajdler, Kancelaria RadcyPrawnego, Significant declines in LNG prices in March 2015, lngsnapshot.com. 


\section{WPLYW ROZWOJU KRAJOWEJ INFRASTRUKTURY GAZOWEJ NA \\ BEZPIECZEŃSTWO ENERGETYCZNE POLSKI}

$\mathrm{Na}$ początku lat 90' zauważono potrzebę zwiększenia bezpieczeństwa energetycznego Polski poprzez dywersyfikację dostaw gazu ziemnego. Ówczesna sieć przesyłowa była dostosowana do importu gazu z kierunku wschodniego. Było to następstwem uwarunkowań historycznych oraz geopolitycznej lokalizacji Polski. Należy zauważyć szereg projektów zrealizowanych na przestrzeni ostatniego dziesięciolecia, tych które są w trakcie realizacji i tych które są w fazie planowania, a które łączy wspólny cel - zwiększenie bezpieczeństwa energetycznego Polski. Inwestycje, o których mowa mają z jednej strony umożliwić import gazu ziemnego do Polski w ilościach wystarczających do całkowitego uniezależnienia się rodzimej gospodarki od dostarczanego $\mathrm{z}$ kierunku wschodniego, a $\mathrm{z}$ drugiej strony przygotować infrastrukturę umożliwiającą sprzedaż i eksport nadmiarowych ilości gazu ziemnego do krajów Europy południowo-zachodniej. W niniejszym artykule poddano ocenie najważniejsze inwestycje, jakie zrealizowano w ostatnim dziesięcioleciu mające na celu zwiększenie bezpieczeństwa dostaw gazu do Polski. Przedstawiono znaczenie powstającego w Świnoujściu terminalu LNG, wymieniono i scharakteryzowano nowo wybudowane oraz rozbudowane połączenia transgraniczne. Zwrócono uwagę na prace związane $\mathrm{z}$ rozbudową podziemnych magazynów gazu. Dodatkowo przeanalizowano trwający proces liberalizacji krajowego rynku gazu ziemnego oraz wzrastające znaczenie Towarowej Giełdy Energii w kontekście handlu paliwem gazowym. W podsumowaniu stwierdzono, że terminal LNG oraz nowe połączenia międzysystemowe są gwarantem bezpieczeństwa energetycznego Polski oraz stanowią podwaliny do pełnej integracji z europejskim rynkiem gazowym.

Słowa kluczowe: gaz ziemny, bezpieczeństwo energetyczne, infrastruktura gazowa, podziemny magazyn gazu.

DOI:10.7862/rz.2016.hss.5

Przesłano do redakcji: czerwiec 2015

Przyjęto do druku: styczeń 2016 